\title{
A new species of Calantica from Western Australian waters (Thoracica: Scalpellomorpha: Calanticidae)
}

\author{
Diana S. Jones and Andrew M. Hosie \\ Western Australian Museum, Locked Bag 49, Welshpool DC, Western Australia 6986, Australia \\ Email: diana.jones@museum.wa.gov.au; andrew.hosie@museum.wa.gov.au
}

\begin{abstract}
A new calanticid species from the tropical waters of Western Australian waters, epizoic on a gorgonian, is described. The presence of 13 capitular plates with apical umbones, arranged in two whorls, narrow peduncular scales and uniarticulate caudal appendages, as well as the attachment site of the complemental males, warrant this species for inclusion within Calantica. Key characters which distinguish the present species from other members of Calantica include the form of the scutum and upper latus, and the elongate rostrolatus and carinolatus, which displace the upper latus from the peduncular margin. Therefore, a new species is proposed and is accordingly named Calantica darwini sp. nov.
\end{abstract}

Key words: stalked barnacle, gorgonian, epibiont, Port Hedland, Rowley Shoals.

\section{INTRODUCTION}

The genus Calantica was first proposed by Gray (1825), but was later synonymised under Scalpellum Leach, 1817 by Darwin (1852). Pilsbry (1907) reinstated Calantica as a subgenus of Scalpellum, elevating it to full generic status the following year (Pilsbry 1908) to encompass six species. Subsequently, Zevina (1978) raised the predominantly Atlantic subgenus Scillaelepas to generic rank, leaving predominantly Indo-West Pacific species with Calantica. Currently comprising 16 species (Young 2003), it has been 20 years since the last species, C. moskalevi Zevina and Galkin, 1989 was assigned to Calantica. The present paper describes a new calanticid species from tropical north Western Australian waters, south of the Rowley Shoals.

\section{MATERIALS AND METHODS}

Specimens were examined with the aid of microscopy and dissection, and illustrations of the whole animal were made with the aid of a camera lucida and digitally inked using a WACOM Intuos 2 tablet and Adobe Illustrator. Soft parts were cleared, stained with lignin pink and mounted. All measurements are in millimetres. The terminology follows that of Jones (1990, 1992, 1993), Newman (1987, 1991, 1996) and Young (1999). The holotype and four lots of paratypes are deposited in the Western Australian Museum, Perth and one lot of paratypes is also deposited in The Natural History Museum, London.

The following abbreviations are used: CL, capitular length; CW, capitular width; PL peduncular length; WAM, Western Australian Museum, Perth; NHM, Natural History Museum, London.

\section{SYSTEMATICS}

\section{Infraclass Cirripedia Burmeister, 1834}

Superorder Thoracica Darwin, 1854

\section{Order Scalpelliformes Buckeridge and Newman, 2006}

\section{Suborder Scalpellomorpha Newman, 1987}

Family Calanticidae Zevina, 1978

\section{Diagnosis}

Scalpelliformes with capitulum protected by six primary calcareous plates or their rudiments, namely rostrum, carina, paired scuta and terga. Secondary plates consist of of three pairs of latera, including rostrolatus, upper latus and carinolatus and (except for Pisiscalpellum) subcarina, plus various other supplementary capitular plates, to a total of $60+$ plates, with as few as nine in reduced forms; umbo of carina apical, sometimes 
subcentral; plates arranged in two more or less distinct whorls, those in lower whorl either overlapping, or being overlapped by adjacent plates. Peduncle usually with more or less uniformsized calcareous scales. Caudal appendages setose, sometimes multi-articulate. Basic mandible with three primary teeth, lower angle pectinate, sometimes smaller secondary teeth form between first and second teeth. Maxillule lacking step-like cutting edge. Small males often associated with larger hermaphrodites or females; males clearly divided into peduncle and capitulum, with six or more small capitular plates.

\section{Remarks}

The family Scalpellidae was divided into eight subfamilies by Zevina (1978), based on the number of capitular plates and their degree of development, the position of the umbos, the number of segments in the caudal appendages and the degree of development of the males. The Calanticinae embraced five genera, namely Calantica Gray, 1825; Euscalpellum Hoek, 1907; Paracalantica Utinomi, 1949; Scillaelepas Seguenza, 1876; and Smilium Gray, 1825. Zevina included Pollicipes Leach, 1817 in the Pollicipinae and Pisiscalpellum Utinomi, 1958 in the Scalpellopsinae.

Buckeridge (1983), in a revision of New Zealand and Australian fossil barnacles based on capitular plate architecture, placed Calantica and Smilium, together with Pollicipes, Pisiscalpellum, Capitulum Oken, 1815 and the fossil genera Zeugmatolepas Withers, 1913 and Titanolepas Withers, 1913 in the Calanticinae. Buckeridge also recognised Scillaelepas as a subgenus of Calantica but placed Euscalpellum in the Scalpellinae.

The subfamily Calanticinae was subsequently raised to full familial status by Newman (1987, 1991, 1996), embracing nine extant genera (Aurivillialepas Newman, 1980; Calantica Gray, 1825 [includes Protomitella Broch, 1922, cf. Foster 1978: 39]; Euscalpellum Hoek, 1907; Gruvelialepas Newman, 1980; Newmanilepas Zevina and Yakhontov, 1987; Paracalantica Utinomi, 1949; Pisiscalpellum Utinomi, 1958; Scillaelepas Seguenza, 1876; and Smilium Gray, 1825) and five fossil genera (Cretiscalpellum Withers, 1922; Titanolepas Withers, 1913; Pachyscalpellum Buckeridge, 1991: 56; Virgiscalpellum Withers, 1935; and Zeascalpellum Buckeridge, 1983). Jones (1998) described a new calanticid genus, Crosnieriella.

\section{Calantica Gray, 1825}

Calantica Gray, 1825: 101.

\section{Diagnosis}

Scalpellids in which hermaphrodites develop, in addition to 6 primary plates, a subcarina, sometimes a subrostrum, and a number of paired latera. Plates generally triangular, umbos apical. Upper latus without a distinct carinal margin. Filamentary processes absent. Caudal appendages uniarticulate, setose. Complemental males may be attached to integument between scuta, below adductor muscle.

\section{Type species}

Calantica homii Gray, 1825 [junior synonym of Calantica villosa (Leach, 1824)], by monotypy.

\section{Remarks}

Calantica has a basic plan of 13 capitular plates, with a total of $60+$ to as few as 11 plates (both extremes occur in C. spinosa (Quoy and Gaimard, 1834). Smilium also has a basic plan of 13 capitular plates, with a total of up to 15 (S. horridum Pilsbry, 1912) and as few as nine plates (S. hypocrites (Barnard, 1924), but the upper latus has a distinct carinal margin. Crosnieriella has a basic plan of 19 capitular plates (C. acanthosubcarinae Jones, 1998). Crosnieriella shares some characters with Calantica, but is most similar to Smilium. However, the apomorphic replication of the plates at the carinal end of the capitulum distinguishes Crosnieriella.

\section{Calantica darwini sp. nov.} Figures 1-2

\section{Material examined}

\section{Holotype}

Australia: Western Australia: hermaphrodite, Soela station $\mathrm{SO} 4 \mathrm{~B} / 82 / 71,18^{\circ} 30.1^{\prime} \mathrm{S} 118^{\circ} 36.2^{\prime} \mathrm{E}$ to $18^{\circ} 31.6^{\prime} \mathrm{S}, 118^{\circ} 37^{\prime} \mathrm{E}, 196 \mathrm{~km} \mathrm{~N}$. of Port Hedland, 136-146 m, 19 August 1982, J. Marshall, attached to gorgonian coral (WAM C42382).

\section{Paratypes}

Australia: Western Australia: 1 hermaphrodite, ovigerous, collected with holotype (WAM C42383); 1 hermaphrodite with 1 complemental male, collected with holotype (WAM C42384); 1 hermaphrodite, abnormal capitulum, with 1 complemental male, collected with holotype (WAM C42385); 5 hermaphrodites, collected with holotype (WAM C33688); 4 hermaphrodites, collected with holotype (NHM 2009.312 - 315).

\section{Etymology}

The species is named in honour of Charles Darwin for his impact on and contribution to cirripediology specifically and biological sciences as a whole.

\section{Diagnosis}

Capitulum of 13 calcareous plates. Lower plates 


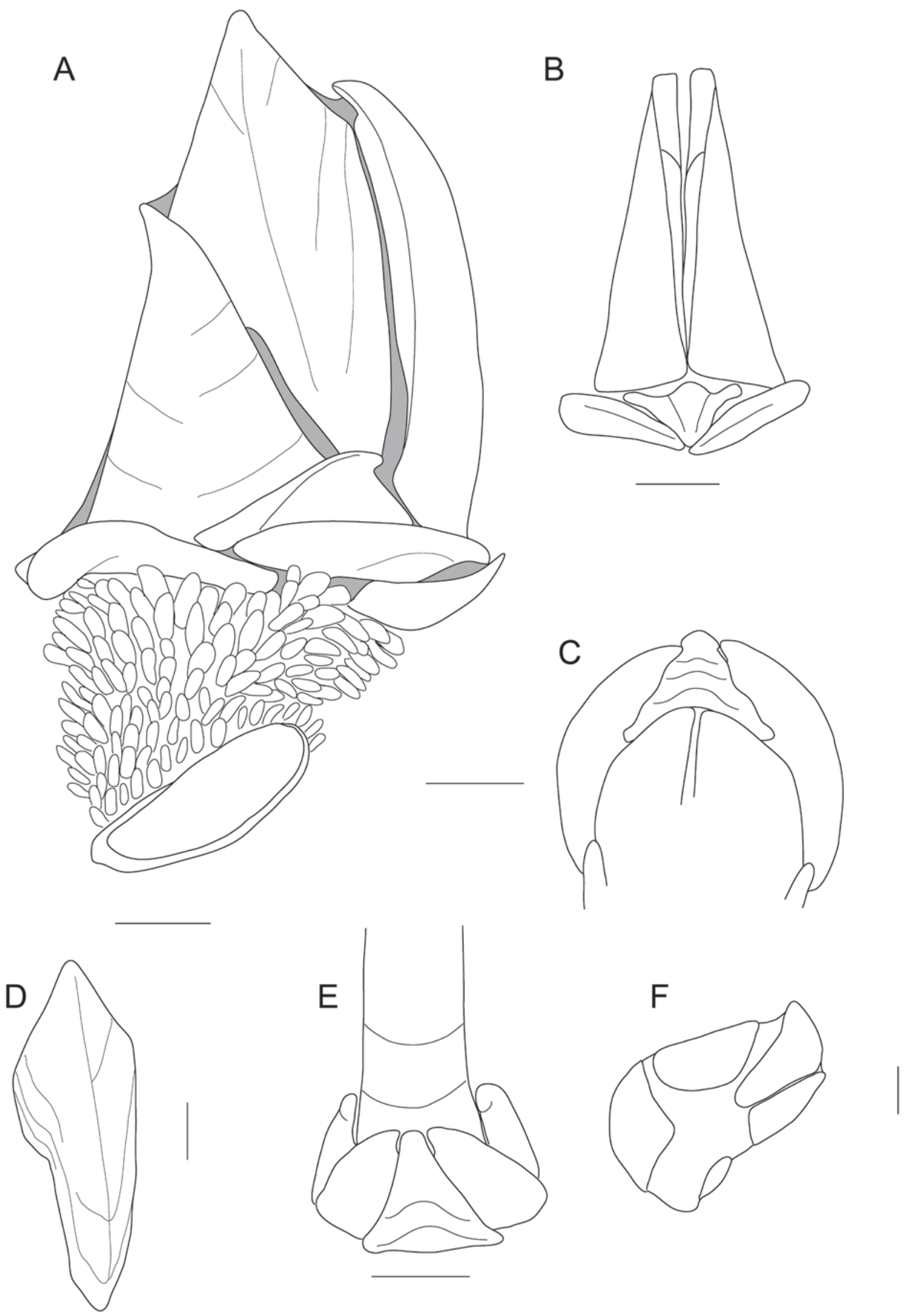

Figure 1 Calantica darwini sp. nov.: A-B, holotype (C42382); C, E, F, paratypes (C42385); D, paratype (C42384): A, lateral view; B, rostral view; $C$, rostral view from above; D, tergum; E, carinal view; F, complemental male. Scale bars: $\mathrm{A}-\mathrm{E}=0.5 \mathrm{~mm} ; \mathrm{F}=0.1 \mathrm{~mm}$ 

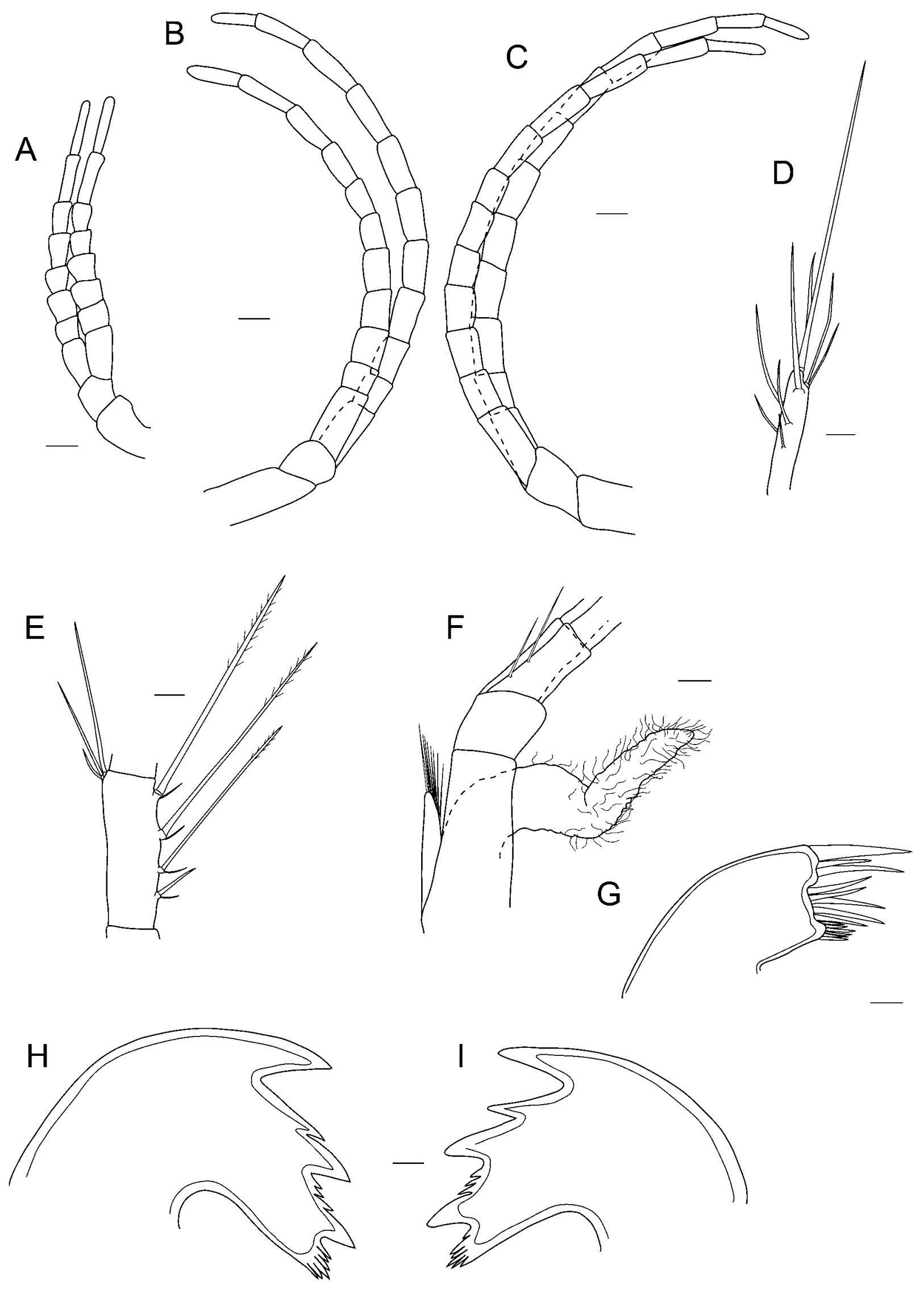

Figure 2 Calantica darwini sp. nov. holotype (C42382): A-C, cirrus I-III respectively; D, terminal segment of cirrus I; E, medial segment of cirrus VI; F, pedicel of cirrus VI; G, left maxillule; H, I, left and right mandibles. Minor setation omitted from mouthparts. Scale bars: A-C $=0.1 \mathrm{~mm} ; \mathrm{D}, \mathrm{E}, \mathrm{G}-\mathrm{I}=0.025 \mathrm{~mm} ; \mathrm{F}=0.05 \mathrm{~mm}$. 
slightly overlapping upper plates. Apex of scutum curving away from tergum. Upper latus with slight articular furrow, excluded from peduncular margin by rostrolatus and carinolatus. Rostrolatus rectangular, elongate, 5 times wider than high, occupying $0.55-0.70$ capitular width, projecting laterally from capitulum, forming small shelf. Carinolatus rectangular, 4 times wider than high, occupying approximately 0.5 capitular width. Subcarina recurved distally. Peduncular scales peg-like, protruding from cuticle in dense rows. Mandible with 3-4 teeth, lower angle pectinate. Maxillule with protuberant superior and inferior angles.

\section{Description}

Hermaphrodite capitulum subtriangular, basic plan of 13 approximate plates. Plates thin, translucent, indistinctly sculptured. Umbones of all plates apical. Apices of lower whorl plates just covering bases of those of upper whorl. Cuticle smooth.

Scutum triangular, shorter than carina, apex curving outwards from tergum; basal margin convex, tergal and scutal margins equal length, 1.5 length of basal margin; internally adductor muscle scar prominent. Tergum highest capitular plate, elongated diamond shape; occludent margin straight, carinal margin evenly convex, scutal margin straight except for small triangular indentation in upper third; weak apico-basal ridge present. Carina transversely bowed, regularly arched for $2 / 3$ length, curve more pronounced in apical third; apex bent towards tergum; internally concave; basal portion rounded. Rostrum smallest capitular plate, triangular, inserted above rostrolatera, projecting out from capitulum; upper surface with low medial ridge. Upper latus triangular, basal margin longest, slightly sinuous; apex curving towards carina, not projecting from capitulum; articular furrow arising from articulation with carinolatus; displaced from basal whorl by rostrolatus and carinolatus. Rostrolatus subrectangular, much wider than high, projecting from capitulum to form small shelf, occupying 0.55-0.70 capitular width; apex curving under rostrum, meeting that of opposite rostrolatus. Carinolatus subtriangular much wider than high, occupying approximately 0.5 capitular width. Subcarina triangular, apex recurved, just overlying basal portion of carina and apices of carinolatera.

Peduncle short, 0.3 capitular length, with elongate peg like calcareous scales sometimes projecting from cuticle.

Labrum strongly bullate, covered with fine setae, denticulate teeth absent. Mandibular palp short, narrow, bearing serrulate setae. Mandible with three primary teeth; smaller, secondary tooth forming just above second primary tooth, upper surface of third tooth serrated; inferior angle strongly denticulate. Maxillule with superior angle projecting, bearing three large seta, remaining setae arranged in pairs, slightly shorter, less robust; inferior angle projecting, bearing dense comb of short, robust setae. Maxilla subtriangular, buccal margin concave; setae serrulate, setae on external margin up to twice length of those on buccal margin.

Chaetotaxy ctenopod. Cirral formula as follows ( ${ }^{+}$denotes broken rami):

$\begin{array}{lcccccccc} & & \text { I } & \text { II } & \text { II } & \text { IV } & \text { V } & \text { VI } & \text { c.a. } \\ \text { Holotype } & \text { L } & 8,8 & 12,11 & 12,12 & 8^{+}, 14 & 13,14 & 12,13 & 1 \\ & \text { R } & 8,8 & 11,11 & 12,11^{+} & 12,12 & 13,12 & 13,13 & 1 \\ \text { Paratype } & \text { L } & 11,8 & 12,11 & 9^{+}, 9^{+} & 13,15 & 11,12 & 12,8^{+} & 1 \\ \text { (C42383) } & \text { R } & 10,10 & 14,13 & 11,12 & 8^{+}, 13 & 13,12 & 13,11 & 1\end{array}$

Gap between cirri I and II absent. Cirrus I with rami subequal in length; basal segments approximately square, densely setose on internal side; distal segments elongate, 3 times higher than wide, setae preset only near distal margin; terminal segment with distal tuft of short setae, plus 1-2 setae more than $2 \times$ length of segment; setae simple and serrulate. Cirrus II with basal segments roughly square, setation similar to that of cirrus I; distal segments becoming elongate, 4 pairs of simple setae on anterior faces. Cirri III-VI similar, segments elongate, 3 times higher than wide, bearing 4-5 pairs of serrulata and simple setae on anterior faces, small setae between pairs; tuft of short setae at posterodistal angles, maximum length not much more than length of subsequent segment; proximal segment of anterior ramus bearing 1-2 well-spaced, long setae on posterior margin. Caudal appendages uniarticulate, leaf-like, with numerous apical setae, height less than height of proximal segment of pedicel. Penis less than half length of cirrus VI, clothed in setae.

Complemental males attached to cuticle of occludent margin of scutum. Capitulum with 6 plates: rostrum, paired scuta and terga and carina. Scutum trapezoidal, approximately same size as tergum. Tergum subtriangular, scutal margin concave in apical third. Rostrum diamond shape, almost twice size of scutum. Carina triangular, higher than wide.

\section{Dimensions}

$\begin{array}{lcccc} & & \text { CL } & \text { CW } & \text { PL } \\ \text { Holotype } & \text { C42382 } & 2.97 & 2.34 & 1.18 \\ \text { Paratypes } & \text { C42383 } & 3.30 & 2.79 & 1.47 \\ & \text { C42384 } & 2.86 & 2.57 & 0.81 \\ & \text { C42385 } & 3.07 & 2.49 & 0.95\end{array}$




\section{Distribution}

This species is presently known only from the tropical waters of northwestern Western Australia, where it has been found to be epizoic on gorgonian coral.

\section{Discussion}

The current species is referable to the genus Calantica owing to the basic arrangement of 13 capitular plates in two more or less consecutive whorls and the peg-like peduncular scales. The upper latus is occluded from the peduncle by the carinolatus and rostrolatus as is the case in Smilium and Euscalpellum. However, these latter genera possess a distinctly trapezoidal upper latus with a distinct carinal margin, as opposed to the triangular upper latus in the present specimens (Zevina 1981; Foster 1979). In Scillaelepas, Gruvelialepas and Aurivillialepas, the lower whorl of capitular plates markedly overlap each other and those of the first whorl (Newman 1980). This has resulted in the formation of articular furrows and ridges. In the new species described herein, the second whorl of plates barely overlaps those of the first whorl and only the upper latus has an articular furrow, although this is weakly developed. In Calantica, the males attach internally to the occludent margin of the scutum, not externally to the rostrum or peduncle as in the latter genera. The genus Crosnieriella, whose capitulum has a basic plan of 19 plates, has a pair of filamentary appendages present on the prosoma, a character not seen in any other calanticid genus (Jones 1998).

The normal arrangement of plates in C. darwini is six primary plates plus three pairs of latera and a subcarina, giving a total of 13 plates. Calanticids are known to have a variable number of capitular plates within species, e.g. Calantica spinosa (Quoy and Gaimard, 1834) and Crosnieriella acanthosubcarinae Jones, 1998. In the material described herein, a few individuals of $C$. darwini show a reduction in the number of capitular plates. The pattern of reduction appears to be asymmetric and affects only the paired latera. One specimen lacked all three latera on the right side (WAM C42385), while another (WAM C33688) lacked the right carinolatera. None of the specimens examined developed more than 13 plates.

The small size, elongated rostrolatera and carinolatera, and the bent carinal apex easily separate the new species from the majority of the species of Calantica. Calantica darwini is most closely related to Calantica pusilla Utinomi, 1970. Both are small species, epizoic on gorgonians. However, C. darwini is readily distinguished by the small shelf formed by the elongated rostrolatera and carinolatera that excludes the upper latus from the peduncular margin. In C. pusilla, the rostrum is relatively smaller and inserted between the rostrolatera, as opposed to above in C. darwini The carina is evenly arched in C. pusilla, without the pronounced apical curve exhibited in C. darwini The apex of the scutum of C. pusilla is erect or recurved towards the tergum, rather than recurved away from the tergum as in C. darwini. Utinomi (1970) described the mouthparts of C. pusilla as being "typical of the genera" and thus a comparison cannot be drawn with those of $C$. darwini.

Of the present material, one of the paratypes (C42383) was found to be ovigerous even though there was no complemental male present, suggesting that the eggs were fertilised by a nearby neighbour or possibly through self-fertilisation. The eggs are relatively large compared to the adult $(\sim 0.4 \mathrm{~mm})$ and only about 15 were present. The length of calanticid penises, whilst variable, is normally shorter than cirrus VI and there is some uncertainty over its functionality (Jones 1998).

\section{ACKNOWLEDGEMENTS}

The authors wish to thank Laura J. Roberts for her help in assembling the figures and to Dr. John Buckeridge, RMIT for his comments and corrections on the manuscript.

\section{REFERENCES}

Annandale, N. (1910). Notes on Cirripedia Pedunculata in the collection of the University of Copenhagen. Videnskabelige Meddelelser fra Dansk Naturhistorisk Forening i Kjøbenhavn 1910: 211-18.

Annandale, N. (1916). Barnacles from deep-sea telegraph cables in the Malay Archipelago. Journal of the Straits Branch of the Royal Asiatic Society 74: 281-302.

Aurivillius, C.W.S. (1892). Neue Cirripeden aus dem Atlantischen, Indischen und Stillen Ocean. Öfversigt af Kongliga Vetenskaps-Akademiens Förhandlingar 3: 123-135.

Barnard, K.H. (1924). Contributions to the crustacean fauna of South Africa. No. 7. Annals of the South African Museum 20: 1-103.

Broch, H. (1922). Papers from Dr. Th. Mortensen's Pacific Expedition 1914-1916. No. X. Studies on Pacific cirripeds. Videnskabelige Meddeleiser fra dansk naturhistorisk Forening i Kjøbenhaven 73: 215-359.

Broch, H. (1931). Papers from Dr. Th. Mortensen's Pacific Expedition 1914-1916. LVI. Indomalayan Cirripedia. Videnskabelige Meddelelser fra Dansk Naturhistorisk Forening i Kjøbenhavn 91: 1-146.

Buckeridge, J.S. (1983). Fossil barnacles (Cirripedia: Thoracica) of New Zealand and Australia. New Zealand Geological Survey Paleontological Bulletin 50: $1-151$.

Buckeridge, J.S. (1991). Pachyscalpellum cramptoni: a new genus and species of lepadomorph cirripede from the Cretaceous of northern Hawke's Bay, New Zealand. Journal of the Royal Society of New Zealand 21: 55-60.

Buckeridge, J.S. and Newman, W.A. (2006). A revision 
of the Iblidae and the stalked barnacles (Crustacea: Cirripedia: Thoracica), including new ordinal, familial and generic taxa, and two new species from New Zealand and Tasmanian waters. Zootaxa 1136: 1-38.

Burmeister, H. (1834). Beiträge zur Naturgeschichte der Rankenfusser (Cirripedia). G. Reimer: Berlin.

Calman, W.T. (1918). On barnacles of the genus Scalpellum from deep-sea telegraph cables. Annals and Magazine of Natural History 9: 96-124.

Darwin, C. (1852). A monograph of the subclass Cirripedia, with figures of all the species. The Lepadidae; or, pedunculated cirripedes. Ray Society: London.

Darwin, C. (1854). A monograph on the subclass Cirripedia, with figures of all the species. The Balanidae, the Verrucidae etc. Ray Society: London.

Foster, B.A. (1979). The Marine Fauna of New Zealand: Barnacles (Cirripedia: Thoracica). New Zealand Oceanographic Institute Memoir 69: 1-160.

Gray, J.E. (1825). A synopsis of the genera of cirripedes arranged in natural families, with a description of some new species. Annals of Philosophy, new series 10(2): 97-107.

Hoek, P. P. C. (1907). The Cirripedia of the Siboga Expedition. A. Cirripedia Pedunculata. Siboga Expeditie Monographe 31a: V-XXV, 1-127. E. J. Brill: Leiden.

Jones, D.S. (1990). The shallow-water barnacles of southern Western Australia. In Wells, F. E., Walker D. I., Kirkman, H. and Lethbridge, R. (eds), Proceedings of the Third International Marine Biological Workshop: The Marine Flora and Fauna of Albany, Western Australia 1988, vol. 1: 333-437. Western Australian Museum: Perth.

Jones, D.S. (1992). Scalpellid barnacles (Cirripedia: Thoracica) from the northeastern and central eastern Australian continental shelf and slope. Memoirs of the Queensland Museum 32: 145-178.

Jones, D.S. (1993). Techniques to investigate the structure of scalpellomorph barnacles (Thoracica: Pedunculata). Journal of Crustacean Biology 13: 343-348.

Jones, D.S. (1998). New genus and species of Calanticidae (Cirripedia: Thoracica: Scalpellomorpha) from Australian waters. Zoosystema 20: 239-253.

Leach, W.E. (1817). Distribution systématique de la classe des Cirripèdes. Journal de Physique, de Chimie et d'Histoire Naturelle, Paris 85: 67-69.

Leach, W.E. (1824). Encyclopedia Britannica, Supplement, Volume 3: 168-171.

Newman, W.A. (1980). A review of extant Scillaelepas (Cirripedia: Scalpellidae) including recognition of new species from the north Atlantic, western Indian Ocean and New Zealand. Tethys 9: 379-398.

Newman, W.A. (1987). Evolution of cirripedes and their major groups. In: A. J. Southward (ed), Barnacle Biology, Crustacean Issues 5: 3-42. A.A. Balkema: Rotterdam.

Newman, W.A. (1991). Cirripedia. In Encyclopedia Britannica, 15th Edition, Vol. 16: 849-854, 859. Chicago, Illinois.

Newman, W.A. (1996). Cirripedia; Suborders Thoracica and Acrothoracica. In Traité de Zoologie, Tome VII, Crustacés, Fascicule 2: 453-540. Masson: Paris.
Newman, W.A., Zullo, V.A. and Withers, T.H. (1969). Cirripedia. In: R. C. Moore (ed.), Treatise of invertebrate palaeontology, Part R: Arthropoda 4: R206-R295. Geological Society of America and the University of Kansas: Lawrence, Kansas.

Oken, L. (1815). Lehrbuch der Naturgeschichte, 3. Teil Zoologie, 1. Abt. Fleischlose Tiere. A. Schmid and Co.: Jena.

Pilsbry, H.A. (1907). The barnacles (Cirripedia) contained in the collections of the United States National Museum. Bulletin of the United States National Museum 60: $1-122$.

Pilsbry, H.A. (1908). On the classification of the scalpelliform barnacles. Proceedings of the Academy of Natural Sciences, Philadelphia 60: 104-111.

Pilsbry, H.A. (1912). Diagnoses of new barnacles from the Philippine Archipelago and the China Sea. Proceedings of the United States National Museum 42: 291-294.

Quoy, J.R.E. and Gaimard, J.P. (1834). Mollusques. Voyage de l'Astrolabe. Zoologie 3: 627-643. J. Tastu: Paris.

Seguenza, G. (1876). Ricercare paleontologiche intorno ai Cirripedi terziarii della Provincia di Messina. Con appendice intorno ai Cirripedi viventi nel Mediterraneo e sui fossili terziarii dell'Italia Meridonale. Parte II. Lepadidae. Atti della Accademia Pontaniana 10: 265-481.

Utinomi, H. (1949). Studies on the cirripedian fauna of Japan. VI. Cirripeds from Kyusyu and Ryukyu Islands. Publications of the Seto Marine Biological Laboratory 1 : 19-37.

Utinomi, H. (1958). Studies on the Cirripedian fauna of Japan. VII. Cirripeds from Sagami Bay. Publications of the Seto Marine Biological Laboratory 6: 281-311.

Utinomi, H. (1970). New and rare commensal pedunculate cirripeds from Amakusa Islands, western Kyushu, Japan. Publications of the Seto Marine Biological Laboratory 18: 157-167.

Weltner, W. (1922). Cirripedia der deutschen TiefseeExpedition. Wissenschaftliche Ergenbnisse der deutschen Tiefsee-Expedition auf dem Damfer "Valdiva" 1898-1899 23: 59-112.

Withers, T.H. (1913). Some Miocene cirripedes of the genera Hexelasma and Scalpellum from New Zealand. Proceedings of the Zoological Society of London 1913: 840-854.

Withers, T.H. (1922). The morphology of some Cretaceous cirripedes. The Annala and Magazine of Natural History 9: 368-379.

Withers, T.H. (1935). Catalogue of fossil Cirripedia in the Department of Geology. 2. (Cretaceous). British Museum (Natural History): London.

Withers, T.H. (1953). Catalogue of fossil Cirripedia in the Department of Geology. 3 (Tertiary). British Museum (Natural History): London.

Young, P.S. (1999). A preliminary assessment of the characters used in the definitions of the subfamilies at present included in the Scalpellidae Pilsbry, 1907 sensu Newman 1996 (Cirripedia, Thoracica). In F. R. Schram and J. C. von Vaupel Klein (Eds), Crustaceans and the biodiversity crisis, proceedings of the 4th international crustacean congress, 1998, vol. 1: 173-193. Brill: Leiden. 
Young, P.S. (2003). Redescription of the calanticids (Cirripedia, Scalpellomorpha) described by Wilhelm Weltner. Mitteilungen aus dem Museum fuer Naturkunde in Berlin Zoologische Reihe 79, 181-201.

Zevina, G.B. (1978). [A new classification of the family Scalpellidae Pilsbry (Cirripedia, Thoracica). 1. Subfamilies Lithotryinae, Calanticinae, Pollicipinae, Scalpellinae, Brochiinae and Scalpellopsinae.] Zoologichesky Zhurnal 57: 998-1007. (In Russian).

Zevina, G. B. (1981). [Barnacles of the suborder Lepadomorpha (Cirripedia, Thoracica) of the World
Ocean. Part 1. Family Scalpellidae.] Opredeliteli Faune SSSR 127: 1-398. (In Russian).

Zevina, G.B. and Galkin, S.V. (1989). [New species of cirripeds (Cirripedia, Thoracica) from thermal waters.] Zoologichesky Zhurnal 68: 134-136. (In Russian).

Zevina, G.B. and Yakhontova, I.V. (1987). [A new barnacle genus of the family Scalpellidae (Crustacea, Cirripedia) from the North Atlantic]. Zoologichesky Zhurnal 66: 1261-1264 (In Russian).

Manuscript received 4 August 2009; accepted 30 August 2009. 